\title{
A bécsi neoreneszánsz Debrecenben. Wágner Gyula igazságügyi palotái
}

\section{Bevezetés}

Debrecen városa a 19. század utolsó évtizedében, hasonlóan más magyar nagyvárosokhoz, nagyléptékü fejlődésen ment keresztül, amely a városképen ma is látható nyomot hagyott. ${ }^{1}$ E fejlődés összefüggött a dualizmus korának politikai, gazdasági, társadalmi és nem utolsó sorban jogrendszerbeli változásaival, s ennek hozadékaként Debrecenben helyet kaptak az újonnan kialakított igazságügyi szervezet fórumai: Magyar Királyi Járásbíróság, Magyar Királyi Törvényszék, Magyar Királyi İtélőtábla. ${ }^{2}$ Ezeknek a bíróságoknak az elhelyezése egyúttal infrastrukturális fejlesztést is jelentett. Ez utóbbi a müködéshez szükséges fizikai tér, azaz az épület megvalósítását jelentette. Ezekről az építkezésekről az elmúlt években többször ejtettem szót az Interdiszciplináris konferencián is. ${ }^{3}$ Jelen tanulmány az épületek megjelenésére, azok építészeti stílusára fókuszál, azt bemutatandó, hogy a Bécs városának építészeti arculatát meghatározó Theophil Hansen-féle stílus, a „griechische Renaissance” formavilága hogyan jelent meg a magyarországi, így a debreceni bírósági épületeken Hansen tanítványának, Wágner Gyulának a közvetítésével.

\section{Ki volt Wágner Gyula?}

Wágner Gyula ${ }^{4}$ az egyik olyan magyar építész, akinek munkássága megkerülhetetlen akkor, amikor a magyarországi igazságügyi épületekről beszélünk. Wágner Gyula nem volt sztárépítész abban az értelemben, mint pl. Ybl Miklós, Steindl Imre, Alpár Ignác vagy Hauszmann Alajos a dualista Magyarországon, s így nevével sem találkozik legtöbbször a nagyközönség. Azonban míg nevével nem találkozunk,

\footnotetext{
${ }^{1}$ Vö. PAPP JózSEF: Debrecen építészete a századforduló évtizedeiben. Hajdú-Bihar Megyei Levéltár Évkönyve XXXIII., Debrecen, 2014. 7-42.

${ }^{2}$ Vö. BALOGH JuDIT: A modern bíráskodás kialakulása és fórumai Debrecenben. Jogszolgáltatás Debrecenben. Szerk.: MEGYERI-PÁLfFI ZolTÁN. Debrecen, 2015. 19-26.

${ }^{3}$ Vö. MegYeri-PÁlffi Zoltán: A debreceni Magyar Királyi Törvényszék egykori épülete. Interdiszciplinaritás a régiókutatásban IV. Szerk.: BARTHA ÁKos - SzÁlKaI TAMÁs, Debrecen, 2014. 31-46. Illetve MegYeRI-PÁlfFi Zoltán: Igazságügyi építkezések Debrecenben. Jogszolgáltatás Debrecenben. Szerk.: MEGYERI-PÁLFFI ZOLTÁN. Debrecen, 2015. 43-57.

${ }^{4} \mathrm{~A}$ név ékezetes írásmódjával kapcsolatban meg kell jegyezni, hogy bár a szakirodalomban a Wagner, azaz az ékezet nélküli írásmód olvasható a legtöbb esetben, azonban maga az építész ékezetes formában hagyta kézjegyét a tervein, így ennek nyomán következetesen e formában használom a nevet.
} 
addig épületeivel annál inkább, hiszen számos (ha nem a legtöbb) igazságügyi épület kapcsolódik hozzá. ${ }^{5}$

Wágner Gyula életéről nagyon kevés információ áll rendelkezésünkre. A Magyar Életrajzi Lexikon ${ }^{6}$ is elég szükszavúan emlékszik meg róla. Wágner 1851. november 28-án született Pesten egy építész család harmadik gyermekeként. Dobrotka Katalin írásában a lexikoni adatoknál bővebb információt olvashatunk a Wágnercsaládról. Eszerint Wágner Gyula édesanyja Redlich Klára volt, aki Wágner Jánoshoz 1846-ban ment feleségül, s házasságukból tizenhárom gyermek született 1848 és 1870 között. ${ }^{7}$ Az édesapa, Wágner János építészként illetve építőmesterként dolgozott, és olyan épületek füződnek a nevéhez, mint a losonci református templom restaurálása (1852-1854), ${ }^{8}$ vagy a mai ELTE BTK B épülete, az egykori élettani intézet a budapesti Múzeum körúti campuson. Illetve több belvárosi lakóház a fövárosban, ${ }^{9}$ valamint a Váci úti lóvasúti indóház. ${ }^{10} \mathrm{~A}$ Budapesti Fővárosi Levéltár adatbázisa ${ }^{11}$ azt sugallja, hogy Wágner János korának igen foglalkoztatott építésze, illetve építömestere volt. Munkássága a kisebb átalakításokra, valamint az új épületek tervezésére és kivitelezésére is kiterjedt, ${ }^{12}$ sőt ez utóbbi tevékenységi körben Ybl Miklóssal is együtt dolgozott, akit a források jó barátjaként is emlegetnek. ${ }^{13} \mathrm{Az}$ apának a kor ízléséhez jól illeszkedő formavilága Gyula építészetén is visszaköszönt.

Gyula testvérei is építészettel foglalkoztak, így Ödön (aki nevéhez füződik a Veszprémi Törvényszék épülete), ${ }^{14}$ és János is építész volt, Ferenc pedig építési rajzoló. ${ }^{15}$ György nevü testvérük tiszti föorvos volt Pesten. ${ }^{16}$

Wágner Gyula a budapesti kir. József Mủegyetem hallgatója volt 1869-1870-ben, majd építészeti tanulmányait a Bécsi Müegyetem mérnöki fakultásán folytatta. ${ }^{17}$

\footnotetext{
${ }^{5}$ Mivel a kutatás jelenlegi fázisában nem áll rendelkezésre egy hivatalos kimutatás Wágner épületeiről, így a szakirodalmi információk, illetve saját adatgyüjtés alapján állítható az, hogy Wágner Gyula nagyszámú magyar igazságügyi épület tervezője volt. A saját adatgyüjtés alapján ez azt jelenti, hogy 3 ítélőtáblai, 22 törvényszéki (benne járásbíróság is), 4 járásbírósági és 7 önálló büntetés-végrehajtási épület tervezése kapcsolódik a nevéhez.

${ }^{6}$ Vö. Magyar Életrajzi Lexikon. Wagner Gyula. http://mek.oszk.hu/00300/00355/ html/ABC16920/16926.htm (a letöltés ideje: 2014. január 27.)

${ }^{7}$ DobrotKa KatALIN: Börtönök tervezöje - Wagner Gyula élete és munkássága. ÖBE - Összefogás a Börtönügyért Egyesület honlapja, 2014. november 13.

http://www.bortonugy.hu/index.asp?i=hirek_reszletek\&id=639 (a letöltés ideje: 2015 . november 13.)

${ }^{8}$ SISA JózSEF (szerk.): A magyar müvészet a 19. században. Épitészet és iparmüvészet. Budapest, 2013. 253.

${ }^{9}$ Többek között erröl árulkodik a müemlékem.hu c. weboldal adatbázisa: Reáltanoda utca 19./Magyar utca 9., Kecskeméti utca 7., Nádor utca 32./Zoltán utca 14. www.muenlekem.hu (a letöltés ideje: 2015. november 16.)

${ }^{10}$ Vö. müemlékem.hu, 1193. sz. http://www.muemlekem.hu/muemlek?id=1193, (a letöltés ideje: 2015. november 16.)

${ }^{11}$ Budapest Főváros Levéltára tervei http://www.archivportal.hu/hu/adatbazisok/osszetett-adatbazisok/ (a letöltés ideje: 2015 november 15.)

${ }^{12}$ Marótzy Katalin is megjegyzi, hogy Wágner Jánost elsősorban romantikus épületek kivételezőjeként tartjuk számon. MARÓTZY KATALIN: Wéber Antal épitészete a magyar historizmusban. Bp., 2009. 50.

${ }^{13}$ V̈. Magyar Életrajzi Lexikon. Wagner János. http://mek.oszk.hu/00300/00355/html/ABC16920/ 16929.htm (a letöltés ideje: 2014. január 27.)

${ }^{14}$ Vö. PusZTai LÁszló: A bírósági épület. Bírósági épületek Magyarországon. KÁllay IstVÁN PuszTAi LÁSZLó - STIPTA IsTVÁN. Bp., 1993. 35.

${ }^{15}$ URBFACE: A Wagner-udvar. Miniszterek, gyárosok, antiszemiták. http://urbface.com/budapest/awagner-udvar (a letöltés ideje: 2015. november 13.)

${ }^{16}$ DobrotKa KATALIN: i. m.
} 
1874 és 1877 között Theophil von Hansennél (1813-1891) ${ }^{18}$ töltött el hét szemesztert a Bécsi Képzőművészeti Akadémián. ${ }^{19}$ Gyula két évvel fiatalabb Ödön nevü testvérével együtt iratkozott be az Akadémiára 1874 októberében, s mindketten 1877-ig voltak ott Hansen mester tanítványai. ${ }^{20}$ Ez az időszak mindenképpen meghatározó volt Wágner Gyula számára, legalábbis épületei formavilága erről tanúskodik.

A bécsi akadémiai éveket követő időszakról nem áll rendelkezésre adat, de feltehetően, miként ez más építészhallgatóknál ${ }^{21}$ is felmerült, Wágnernek is el kellett három évet töltenie gyakorlat szerzéssel, hogy végül a felsőfokú tanulmányai igazolása mellett megszerezhesse az építőmesteri jogot is. Lehetséges, hogy ezt az időt apja, Wágner János mellett töltötte, akinek számtalan megbízatása volt ekkor. A család - ahogy az életrajzi adatok is mutatják - a korszak egyik építészdinasztiája volt. Feltételezhetően az apa és fiai együtt dolgoztak már a fiúk fiatal évei alatt is. Ami biztosnak mondható, hogy saját irodát müködtettek, amely a család lakhelyével együtt a Hatvani, majd az átnevezés után Kossuth Lajos utca 14-16. szám alatti maguk építtette bérházban kapott helyet. ${ }^{22}$

Mindenesetre az 1880-as évek elején már tervező építészként találkozunk nevével, méghozzá a szegedi kerületi börtönnél, ismertebb nevén a Csilagbörtönnél. Ezt követően egyik megbízást kapta a másik után, amely következtében a dualizmus korában az igazságügyi tárca „házi építészeként” tartották számon. Nem véletlenül, hiszen nevéhez füződik számos bírósági (elsősorban törvényszéki, kevésbé járásbírósági) és büntetés-végrehajtási épület tervezése, miként erre már utaltam.

A magánéletéról még kevesebb adat áll rendelkezésünkre. Hogy milyen ember lehetett az, akit az állam ilyen fontos megbízásokkal látott el, talán érdeklödésre tarthat számot. Egy kapaszkodónk adódik a kérdés megválaszolásához, ugyanis Katkó István Börtönkalauz kezdö bünözők számára c. müvében ${ }^{23}$ Wágner Gyulával mint „regényhössel” találkozhatunk. A regény a börtönépítő Wágnerrel foglalkozik, $\mathrm{s}$ az általa tervezett büntetés-végrehajtási épületek mindegyikét megjárt fogvatartott szemszögéből ismerhetjük meg az építészt. A mü egy szerény, megbízásainak lelki-

\footnotetext{
${ }^{17}$ DobrotKa Katalin: i. m. Ehhez hozzá kell tenni, hogy maga az intézmény 1856 óta müködött mint József Politechnikum, s majd 1871-től változott meg jogi helyzete, és lett József Műegyetem. Vö. SisA JÓZSEF (szerk.): i. m., 338-339.

${ }^{18}$ Vö. Pallas Nagy Lexikona. Hansen, Teofil. http://mek.oszk.hu/00000/00060/html/045/ pc004528.html\#5 (a letöltés ideje: 2014. január 27.)

${ }^{19}$ ZeESE, ANDREAS: Theophil Hansen als Lehrer an der Akademie der bildenden Künste 1868-1884. Theophil Hansen. Architekt und Designer. Szerk.: Reiter, Cornelia - Stalla, Robert, Wien, 2013. 93.

${ }^{20}$ FleISCHER GyUla: Magyarok a bécsi Képzömüvészeti Akadémián, Bp., 1935. 94.

${ }^{21}$ PAPP GÁBOR GYÖRGY: Gerster Kálmán (1850-1927) munkássága. (Doktori disszertáció) 2007. 13.

${ }^{22}$ Vö. urbface.com leírása a Wagner-udvarról: A palota helyén két emeletes ház állt, amelyeket a Kossuth Lajos utca kiszélesítése miatt bontottak le. A 14-es házszámú épület utolsó tulajdonosa özvegy Ruprechtné Avoczky Erzsébet magánzóé volt. Itt élt ifjabb nagybossányi Bossányi István (1861-19?) ítélőtáblai királyi tanácsjegyző és Lappert György sajtkereskedö. A 16-os házszámú emeletes épülete még 1861-ben építtette Zunky Borbála. Az építész Pán József volt. Itt élt 1875-töl 1876-ig SztányiUlmann Károly bankár, a Pesti Magyar Kereskedelmi Bank alelnöke, Mönnig Adolf hangszerész, illetve 1889-től Wagner János építőmester. Ez utóbbi úriember miután 1890-ben megvette és lebontatta mind a két épületet, a saját tervei alapján 1896-1897 között a telekre felépíttetett egy négyemeletes, eklektikus stílusú bérházat. A tervezésben és a kivitelezésben sokat segítettek az építőmesternek testvérei: Wagner Lajos épitész, Wagner Gyula építész, Wagner Ödön építész és Wagner Ferenc építési rajzoló is. http://urbface.com/budapest/a-wagner-udvar (a letöltés ideje: 2015. november 13.)

${ }^{23}$ KATKÓ IsTVÁN: Börtönkalauz kezdö bünözök számára. Bp., 1985.
} 
ismeretesen eleget tevő szakember képét rajzolja meg, aki nemcsak épületeit illetően volt elsősorban a költségek tekintetében visszafogott, hanem magánéletében is. Alaposságát és elhivatottságát támasztja alá az a szakirodalomból kiolvasható élettörténeti adalék 1901-ből, amellyel az esztergomi bíróságról szóló könyvben találkozhatunk: „,Wágner Gyula július végén - talán éppen nyári üdülésének helyszinéröl Zell am See-böl a városhoz intézett levelében tájékoztatást kért a leendö épitkezés helyszinéröl. Az építész a helyi viszonyok ismeretének nem lévén birtokában, az alábbi kérdésekre keresett választ: milyen magasan fekszik a járdaszint az Adria tengerhez viszonyitva, milyen anyagból készüljön a járda, beton, aszfalt vagy trachyt kockaköböl, hogyan oszlik meg a járdaépités költsége az építtetö és a város közt...,24

Csaknem három évtizeden keresztül munkálkodott Wágner Gyula a magyarországi igazságügyi épületek építésében. Úgy tünik, hogy az egri Törvényszéki Palota (1906-1908) volt utolsó munkája, s ezt követően nem tervezett. Nehéz megmondani, hogy mi lehetett az oka kivonulásának. Katkó István regénye talán éppen e kérdésre adandó válaszként született, s egy olyan, a pályája csúcsán lévő építészről mesél, akit „,apró” megingását követően kíméletesen távolítottak el a közéletből.

Nem tudni, mi az igazság, csak annyit, hogy a mester az első világháborút követő években második feleségével, Franz Gabriellával Bécsben élt ${ }^{25}$ a XVIII. kerületi, Gentzgasse 127 . szám ${ }^{26}$ alatti lakásukban, s itt hunyt el 1937. október 15 -én. ${ }^{27}$

\section{Wágner Gyula, az igazságügyi épületek specialistája}

Érdekes eleme egy építész pályafutásának az, hogy hogyan válik egy(-egy) épülettípus specialistájává. Mikor és hogyan következik be az a fordulópont az életében, amelytől kezdve egy adott funkció építészeti megoldásainak ő válik az (egyik) ismerőjévé.

Wágner Gyula életében nehéz ezt a fordulópontot megtalálni. Az egyik legkorábbi adat, amely jelzi számunkra, hogy Wagner találkozott igazságügyhöz kapcsolódó épület tervezésével a szegedi Csillagbörtön volt (1883-1884).

Hogy milyen út vezetett el ahhoz, hogy az igazságügyi épületek specialistájává váljon, kérdéses. Minden estre az adatok azt mutatják, hogy a börtönépítésen keresztül talált utat a bíróságok irányába, ami evidencia, hiszen e két igazságügyi épülettípus szorosan összefügg egymással, ugyanakkor mégis szorosan vett funkciójukból következően karakterük eltér egymástól. Éppen ezért érdemes öket Wágner Gyula életmüvében is külön taglalni.

\footnotetext{
${ }^{24}$ KÁNTOR KLÁRA: Fejezetek a Komárom-Esztergom megyei biróságok történetéből 1872-2009. Komárom, 2009. 48.

${ }^{25}$ DOBROTKA Katalin: i. m.

${ }^{26}$ Jahres-Bericht des Hansen-Klubs in Wien. XXVIII. und XXIX. Klubjahr 1913 und 1914. 36. und 37. Jahr der Vereinigung ehemaliger Hansen-Schüler. Wien, 1915. 79.

${ }^{27}$ Vö. Magyar Életrajzi Lexikon. Wagner Gyula. http://mek.oszk.hu/00300/00355/html/ ABC16920/16926.htm (a letöltés ideje: 2014. január 27.)
} 


\section{Büntetés-végrehajtási épületek}

A polgári átalakulást megelőzően Magyarországon nem létesültek korszerü börtönök. Bár az 1843/44-es javaslatok nyomán készültek tervek, de ezek nem valósulhattak meg. A forradalom és szabadságharc leverését követően hatályba léptették Magyarországon is az 1852. évi osztrák büntetö törvénykönyvet, amelyben a hangsúly a szabadságvesztés-büntetésen volt, azonban ennek végrehajtására nem álltak rendelkezésre megfelelő épületek az országban. Az igazságügyi minisztérium éppen ezért nekilátott az országos intézményrendszer kiépítésének, s 1854 és 1857 között megnyitották az illavai, a váci, a munkácsi, a lipótvári, a márianosztrai és a nagyenyedi fegyintézeteket, valamint közéjük sorolták e szinten a szamosújvári intézményt. Ezek a létesítmények viszont már meglévő, korábban más funkciót teljesítő épületek voltak, s az igazságügy célja ekkor nem feltétlenül a minden korigényt kielégítő infrastruktúra kialakítása volt. Ezekkel az országos intézetekkel szemben a vármegyei büntetés-végrehajtási létesítmények más utat jártak be. Létrehozásuk összekapcsolódott az 1869. évi IV. törvénycikk alapjain kialakított bírósági szervezet kiépítésével, amelynek szerencsés következménye lett, hogy mind az ítélkezés, mind a büntetés-végrehajtás infrastrukturális háttere a következö évtizedekben a lehető legkorszerübb formában épült ki Magyarországon. ${ }^{28}$

Mindeközben zajlott a magyar jogrendszer modernizációját szolgáló kodifikáció, amely a büntetés-végrehajtás terén is újat hozott. Ennek alapját az 1878. évi V. törvénycikk, az ún. Csemegi-kódex jelentette, amely 1880-as hatálybalépésével kijelölte a feladatot az országos fegyintézetek, a kerületi börtönök, a törvényszéki és járásbírósági fogházak, valamint az államfogházak létrehozása, illetve építése tekintetében is. A Csemegi-kódex rendelkezéseinek végrehajtása illetve az infrastrukturális igények legalább részbeni kielégítése végett az igazságügyi miniszter 1880. augusztus 9-én kelt 2106. sz. utasításában intézkedett, amely során elsősorban szervezeti átalakításokra került sor. ${ }^{29}$

Mivel ekkoriban a börtön és a fogház fokozathoz tartozó épületállomány hiányzott, így ezen a szinten indult meg országszerte az építkezés, amelynek a terméke egy komplex épülettípus, az igazságügyi palota lett. E multifunkcionális épület egyszerre felelt meg a korszerú eljárásjogi igényeknek, közöttük hangsúlyosan a nyilvánosság követelményeinek, és büntetés-végrehajtás éppen ezzel ellenkező, zárt világának. E komplexitás speciális építészeti feladatot jelentett, amellyel a korszak építészeinek meg kellett birkóznia. E terület specialistájává vált Wágner Gyula, aki karrierjét az 1880-as évek elején e börtönépítési programba bekapcsolódva alapozta meg.

\section{Bírósági épületek}

Az igazságügyi épületek körében a másik kategóriát a bírósági, azaz az eljárásnak otthont adó épületek képzik. A magyar bírósági épületek kialakítása a kor általános

\footnotetext{
${ }^{28}$ Vö. MEZEY BARNA: A börtönrendszerek és a börtönépítészet a századforduló idején. Börtönügyi Szemle, 1. (2006) 37-39.

${ }^{29}$ Vö: MEgYeRY IsTVÁN: A magyar börtönügy és az országos letartóztatási intézetek. Bp., 1905. 237.
} 
igényeihez is igazodott. Ez alatt az is értendő, hogy nemcsak a magyar specialitások, hanem a korszak európai tendenciái is felfedezhetők az épületeken. Ez nemcsak a stílusbeli hasonlóságok létét jelenti, hanem az alaprajzi alakítás hasonlósságát is. Elsősorban a német nyelvterületen már kiforrott minták átvétele volt kézenfekvő. Az ekkor már Németországban kialakult a sémát, amelyet az igazságügyi épületek alaprajzi alakításánál használtak, olyan alapvető építészeti lexikonok, kézikönyvek magyarázták, mint pl. a Handbuch der Architektur, ${ }^{30}$ vagy GrundrißVorbilder von Gebäuden aller $\mathrm{Art}^{31} \mathrm{c}$. munkák. Bizonyára Wágner is ismerte ezeket, hiszen bécsi tanulmányai és az akadémiai kötelék későbbi fenntartása ${ }^{32}$ ezt joggal engedik feltételezni, továbbá a kor építészeinek magánkönyvtárában is helyet kaptak a német és az európai tendenciákat ismertető magyar építészeti szaklapok ${ }^{33}$ könyvek, kiadványok. ${ }^{34}$

\section{Wágner Gyula debreceni épületei}

Az 1867-es kiegyezést követően nem volt kérdés az, hogy Debrecen - mint ahogyan korábban is - otthont ad a bíráskodás különböző fórumainak, amelyeket a modernizációt követően már állami feladatként szerveztek meg. ${ }^{35}$ A bíróságok elhelyezési gondjainak megoldása hosszú évekbe kerültt, ${ }^{36}$ de végül két olyan korszerü épülettel gazdagodott a város, amelyek ma is hirdetik a dualizmuskori Magyarország és Debrecen város áldozatkészségét. Az egyik épület a Széchényi utcán ma is álló egykori Királyi Ítélőtábla ${ }^{37}$ (ma Debreceni Törvényszék), a másik a mai Iparkamara utcai, a II. világháború után csonkán maradt egykori Királyi Törvényszék (ma BV intézet, illetve 2015-ig a Debreceni Járásbíróság székhelye volt).

Wágner Gyula tervezte ezeket az épületeket, amelyeknek alaprajzi kialakítása messzemenően megfelelt az akkori szervezeti és eljárásjogi követelményeknek. Azonban hủen bevezető gondolatokhoz e tanulmányban a külsőt vesszük szemügyre

\footnotetext{
${ }^{30}$ Vö. F. Bluntschli - KortüM, Albert - LANDAuer, TheOdor von - Meyer, H. - Osthoff, GeOrG - Richter, Friedrich - Schitt, Eduard - Schwechten, Franz - Wagner, Heinrich - Wallot, PAUL: Gebäude für Verwaltung, Rechtspflege und Gesetzgebung; Militärbauten. - Stadt- und Rathäuser. Gebäude für Ministerien (...). Handbuch der Architektur 7. Halbband, Heft 1. Darmstadt, 1887.

${ }^{31}$ Klasen, Ludwig: Grundriß-Vorbilder von Gebäuden aller Art, Handbuch für Baubehörden, Bauherren, Architekten, Ingenieure, Baumeister, Bauunternehmer, Bauhandwerker und technische Lehranstalten, Bd.: 13. Gebäude für Justizzwecke. Leipzig, 1891.

${ }^{32}$ Wágner tagja volt a Hansen-Klubnak. Jahres-Bericht des Hansen-Klubs in Wien. XXVIII. und XXIX. Klubjahr 1913 und 1914. 36. und 37. Jahr der Vereinigung ehemaliger Hansen-Schüler. Wien, 1915. 79.

${ }^{33}$ Vö. MARÓtZy KATALIN: Mintakövetés és invenció a XIX. század második felének budapesti építészetében. Épités- Épitészettudomány, 33. (2005) 1-2. sz. 36-37.

${ }^{34}$ Vö. SiSA JÓZSEF (szerk.): i. m., 350.

${ }^{35}$ Ennek alapja volt a bíráskodást és közigazgatást elválasztó 1869. évi IV. törvénycikk.

${ }^{36}$ Vö. PAPP JÓZSEF: Törvénykezési helyszínek Debrecenben a 20. századig. Jogszolgáltatás Debrecenben. Szerk.: MEgYeRI-PÁlfFi ZolTÁn. Debrecen, 2015. 37-38.

${ }^{37}$ Megszervezéséről lásd: ANTAL TAMÁs: Törvénykezési reformok Magyarországon (1890-1900). İtélőtáblák, birói jogviszony, esküdtszék. Szeged, 2006. 65-73.
} 
(1. kép).$^{38}$ Mindkét épület Wágner tipikus munkájának tekinthető. Ezt a „tipikus” jelzőt mind a tömeg-, mind pedig a homlokzatalakítás miatt érdemlik ki ezek a házak, ugyanis az alkalmazott építészeti megoldások Wágner más városokban felépített munkáiban is felismerhetők.

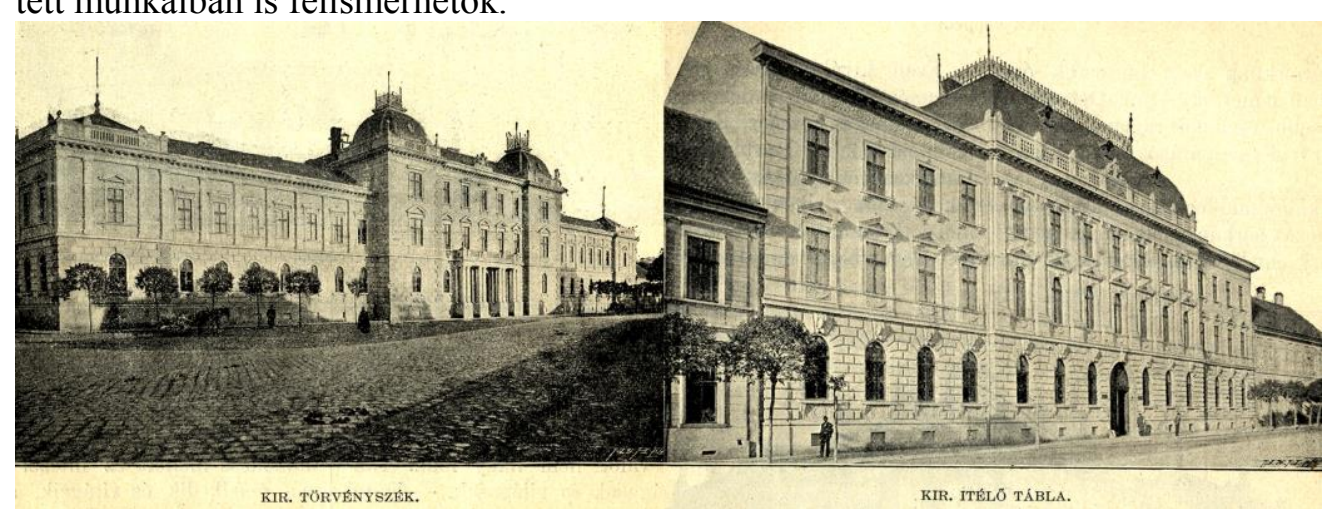

1. kép. A Királyi Törvényszék és a Királyi Ítélőtábla a 19-20. sz. fordulóján.

\section{Az egykori ítélőtábla épülete}

A Királyi Î́télőtábla épülete tulajdonképpen két épület, s ezzel összefüggésben meg kell említeni, hogy két fázisban épült fel. A mai Simonffy utcai egyemeletes szárny készült el hamarabb (1890-1891), majd ezt követte a mai Széchenyi utcai kétemeletes főszárny (1895-1896), ${ }^{39}$ amelynek homlokzata a vizsgálat tárgya. Az épület szerencsésebben átvészelte az 1944-es légitámadásokat, mint a Törvényszéki Palota, ${ }^{40}$ ennek köszönhetően homlokzata javarészt ma is tükrözi az eredeti állapotot.

Az egykori Királyi Ítélőtábla főszárnya, azaz a mai Széchenyi utcai épület kétemeletes, középrizalittal hangsúlyozott homlokzattal rendelkezik. A nyíláskiosztás a következőképpen alakult: 4+7+4, amelyböl kitünik, hogy a középrizalit viszonylag széles volt. Ez az arány összhangban volt az épület tömegével, amelynek fontos eleme volt, a háború után helyre nem állított íves manzárdkupola a középső traktuson. Ezzel a tetővel az épület még monumentálisabban hatott, s kifejezetten felé nőtt az utca egyemeletes házainak (1. kép).

Maga az építészeti megoldás nem volt ismeretlen Wágner Gyula repertoárjában. Számos bírósági épületén felfedezhető ez a középhangsúlyos épülettömeg, amelyet tovább fokoz egy kupolaszerü, íves manzárddal. Ha hasonló karakterü, zártsorú beépítésủ épületeket keresünk az életmüben, akkor könnyen a szemünkbe ötlik a szombathelyi törvényszék bővítése (1903), vagy a makói járásbíróság (1896) ugyan egy emelettel alacsonyabb, de koncepciójában a debrecenivel megegyező épülete. Ugyanide sorolható a máramarosszigeti törvényszék (1896) is, bár ez egy saroképület, de a főhomlokzata hasonlóképpen szerveződik, mint a debrecenié. Ezeken kívül ugyanilyen középkupolás hangsúlyokkal találkozhatunk Wágner aradi

\footnotetext{
${ }^{38}$ Képek forrása: Debreceni Képes Kalendárium. Debrecen, 1903. 52.

${ }^{39}$ Vö. PAPP JÓZSEF: Debrecen építészete... 22.

${ }^{40}$ Vö. KovÁCs ILONA: Igazságszolgáltatás bombatűzben. Jogszolgáltatás Debrecenben. Szerk.: MEgYeRi-PÁlfFi Zoltán. Debrecen, 2015. 62-63.
} 
(1897-1899), székesfehérvári (1902), kolozsvári (1900-1902) és egri (1906-1908) épületein is (2. kép) ${ }^{41}$

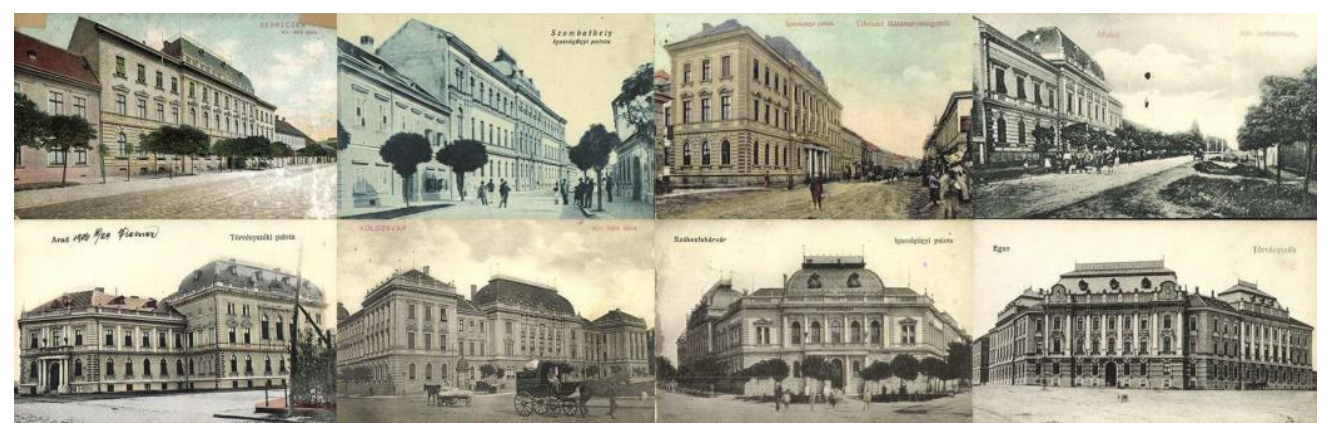

2. kép. Wágner Gyula középkupolás bírósági épületei: Debrecen, Szombathely, Máramarossziget, Makó, Arad, Kolozsvár, Székesfehérvár, Eger.

Ez a forma nem volt ismeretlen a neoreneszánsz ízlésvilágában. Wágner bécsi mesterénél, Theophil Hansennél is feltünik. Ebből a szempontból A Wilhelm föherceg számára építendő palota (Palais Erzherzog Wilhelm) F jelü terve keltheti fel az érdeklődésünket. (3/b kép) A palotához Hansen több tervváltozatot is készített. Az F jelủ tervnél a legnagyobb különbség a korábbi tervváltozatokhoz képest az volt, hogy a középrizalitot egy kupolás magastető fedte, ami a kolonnád mellet egy további szimbóluma volt a megrendelő társadalmi rangjának (Hoheitssymbol). Renate Wagner-Rieger szerint ez francia előkép után született, amely különösen a Pavillon d'horloge des Louvre (Órapavilon) épületén jelenik meg. ${ }^{42}$ (3/a kép) Maria Schludermann diplomamunkájában Klaus Eggert megállapítását is hangsúlyozza, aki rámutatott 1862 közelségére, amikor Arnold von Zanetti és Heinrich Adam felépítette a szintén kupolás középrizalitos Württemberg Palotát. ${ }^{43}$ (3. kép) $)^{44}$

\footnotetext{
${ }^{41}$ Képek forrása: Hungaricana Képeslapok adatbázisa http://postcards.hungaricana.hu/hu/ (a letöltés ideje: 2016. február 18.)

${ }^{42}$ Wagner-Rieger, Renate: Das Palais Erzherzog Wilhelm am Parkring in Wien. Burgen und Schlösser in Österreich, 5 (1969) 24.

${ }^{43}$ Schludermann, Maria: Das Palais Erzherzog Wilhelm von Theophil Hansen. (Diplomarbeit, Universiät Wien) Bécs, 2012. 63-64.

${ }^{44}$ Képek forrása: a) SCHLUdermann, MaRia: i. m., 132.

b) King of Hearts: The Cour Carrée of the "Old Louvre" looking west

https://upload.wikimedia.org/wikipedia/commons/1/11/Louvre_Cour_Carr\%C3\%A9e_June_2010.jpg (a letöltés ideje: 2016. február 18.)

c) „Das Hotel Imperial in der ursprünglichen Bauform, Aufnahme aus dem Jahr 1880” MicHAEL FRANKENSTEIN - ZeFFIRO CiUfFoletti: Das Reich der Habsburger 1848-1918 - Photographien aus der österreichisch-ungarischen Monarchie, Verlag Christian Brandstätter, 2001.

https://upload.wikimedia.org/wikipedia/commons/4/45/Hotel_imperial_1880.png (a letöltés ideje: 2016. február 18.)
} 


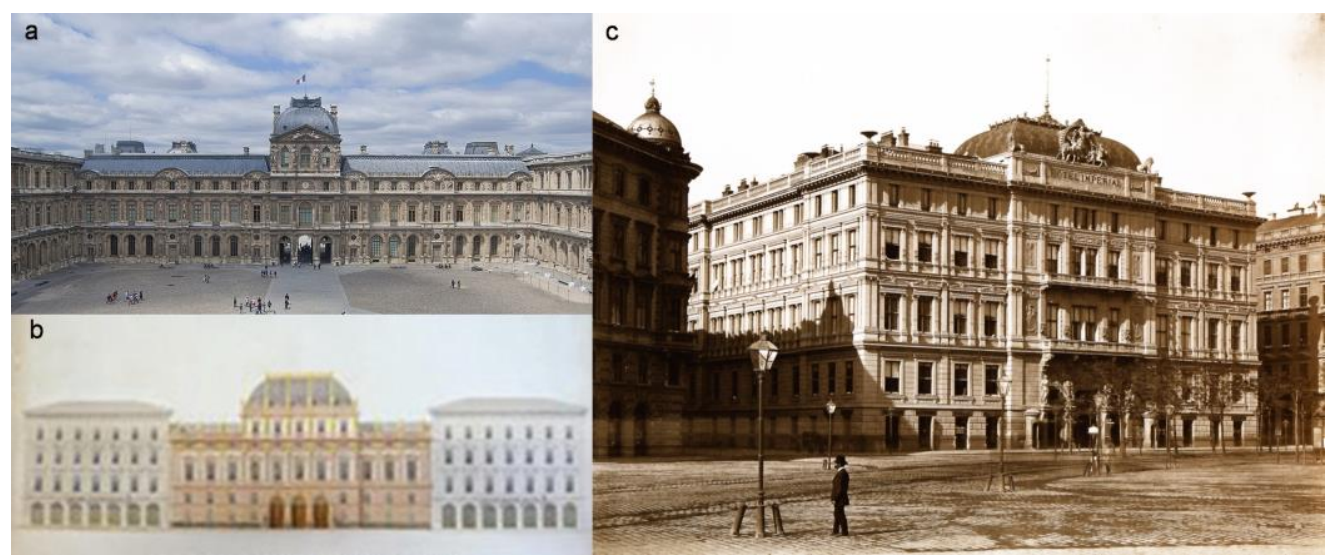

3. kép. Középkupolás előképek: az 1624-1654 között épült Pavillon d'horloge des Louvre (a), Hansen F jelü terve 1864-ből az Erzherzog Wilhelm Palotához (b), és a Württemberg Palota, a későbbi Hotel Imperial egy 1880-as felvételen (c).

A debreceni Széchenyi utcai épület homlokzati rendszere is ezt a középhangsúlyosságot szolgálja. A 7 tengelyes középrizalit nemcsak szélességével, hanem ún. nagyoszloprendjével is nyomatékosítja a monumentalitást. Ez a nagyoszloprendes homlokzati megoldás szintén ismert Hansen életmüvében, így pl. a bécsi Ephrussi Palotán, illetve a Parlamenten is megjelent. Ugyanakkor ezt a sajátos későreneszánsz, barokk palotákra jellemző oszloprendet mind Hansen, mind pedig tanítványa, Wágner, a korai reneszánsz palotáknál ismert hármas homlokzati tagolással kombinálta. A hanseni életmüben e formálás első megjelenése egy adott épülethez köthetö, amellyel fordulópont következett be Hansen stílusában. Ez az épület a bécsi Sina Palota volt, amely homlokzatának újjáépítésekor alkalmazott első ízben reneszánsz formaelemeket. Ahogy Maria Schludermann írja, Hansen itt három részre osztotta a felületet. A földszintet is magába foglaló kváderezett lábazati rész félköríves kapukkal készült, amelyet a középrizalitban oszlopos elöépítmény (portikusz) hangsúlyozott. Négy páros oszlop keretezte a három kaput és tartotta az első emeleti erkélyt, amelynek baluszterei az első és a második emeleti ablakok mellvédfalán megismétlődött. A második emeleti erkélyt kariatidák támasztották alá az oszlopok felett. Az első és a második emeleti ablakokat vertikálisan összekötötte egymással, a harmadik emeleti ablaksor szabadon jelent meg a falfelületen. Ez a háromemeletes zóna egy erőteljes párkánnyal volt elválasztva a harmadik felületi egységtől, ahol a kis ablakok között női fejekkel díszített páros konzolok sorakoztak. ${ }^{45}$

Számunkra ez a leírás azért bír jelentőséggel, mert a Hansen-tanítvány, Wágner is követte e neoreneszánsz palotahomlokzat formálási módot. Különösen kiemelendő a lábazati zóna kvadrátkövekkel való díszítése és félköríves nyílásai, amelyek tipikusak voltak Wágner épületein. Jó példa erre a vizsgált épületünk, az egykori debreceni ítélőtábla, amelynek lábazati zónája ma is őrzi ezeket az elemeket: Az épület részben alápincézett, így földszintje az utcaszinttől magasabban helyezkedik el. A homlokzati kialakítás az alagsori és magasföldszinti szinteket egy lábazati zónaként fogja össze. Ez a lábazati zóna az említett kváderezett falfelületek révén

${ }^{45}$ Vö. SCHLUDERMANN, MARIA: i. m., 42-43. 
megalapozottságot sugall a szemlélőnek. A lábazatot övpárkány választja el a rajta nyugvó emeleti szintektől. Az első és második emelet egy homlokzati felületként jelenik meg, amelyet csak a középrizalit pillérei tagolnak vertikálisan. Kisebb volumenben, de a bécsi Sina Palotához hasonlóan, a debreceni épületen is felfedezhetö az ablaknyílások Hansenre jellemző összerendezése. A Sina Palotán az első és második emeleti ablaksor vertikálisan volt összekötve, míg a harmadik emeleti ablakok szabadon álltak. A debreceni épületnél egy emeleti szint hiányzik e rendszerből, de mégis az elv követhető: az első emeleti ablaksor mellvédjei csaknem összeforrnak az övpárkánnyal, míg a második emeleti ablaksor szabadon lebeg a felületen.

$\mathrm{Az}$ emeleti szintek zónáit szépen kialakított, erőteljesen előre ugró koronázópárkány zárja, amelyen csak a középrizalitban magasodik baluszterrel tagolt attika, ami az egykori manzárdkupolát támasztotta alá (4. kép). ${ }^{46}$

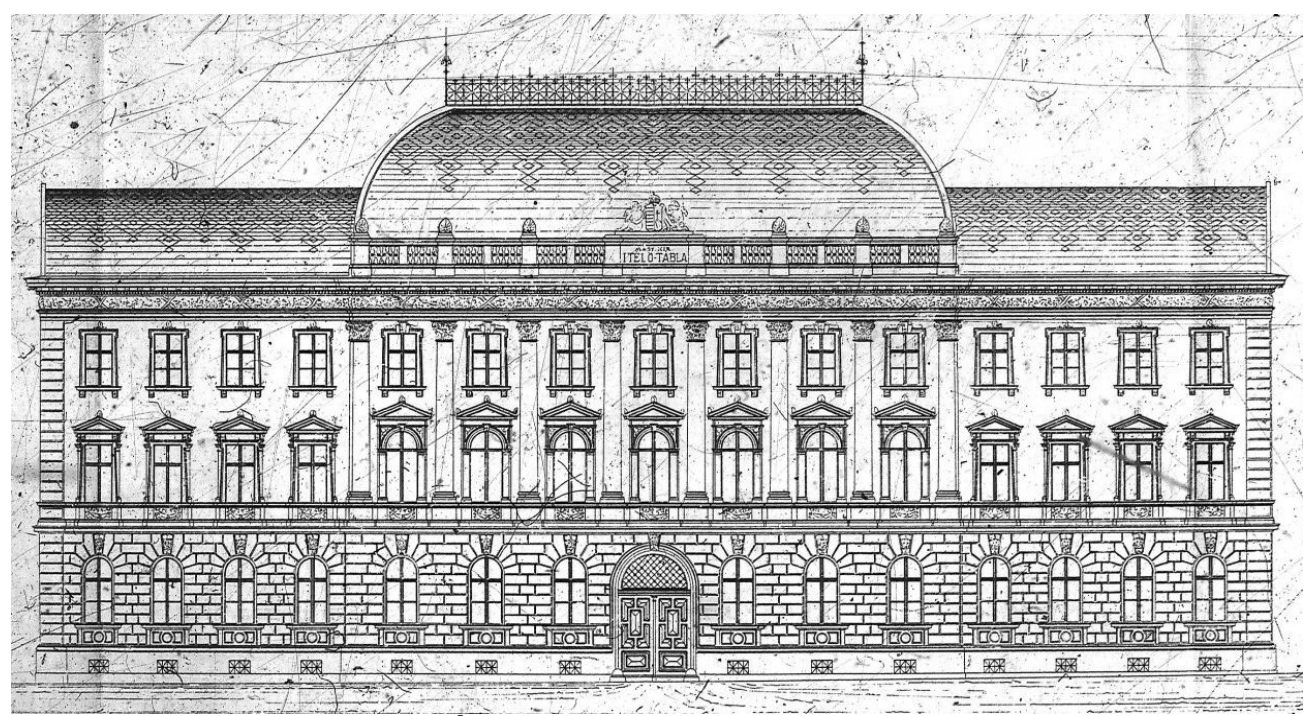

4. kép. A debreceni Királyi Ítélőtábla Wágner Gyula által készített homlokzatterve.

A homlokzat tagolása mellett a részletelemek tükrözik igazán a hanseni formavilágot, amelyet a tanítvány, Wágner Gyula is magáévá tett. Említést érdemelnek a pilaszterek fejezetei. Ezek, a sokszor korinthoszi oszlopfőként emlegetett elemek, Hansen kedvelt formái voltak. Kifejezetten görög antik hatásúak, ami annak köszönhető, hogy Hansen ifjú építészként hosszabb időt töltött el Athénban, ahol alkalma nyílt az antik emlékek restaurálására is. Így készítette el a Lüszikratészemlékmü korinthoszi oszlopfőjének rekonstrukciós rajzát. Ez a forma több épületén is megjelent, így többek között ismét a bécsi Parlament, vagy az Ephrussi Palota alkalmas e szempontból példaként való említésre (5. kép).$^{47}$ Ez utóbbi, az Ephrussi

\footnotetext{
${ }^{46}$ Kép forrása: Debrecen Megyei Jogú Város Polgármesteri Hivatala, Mikrofilmes Adattár, Széchenyi utca 9.

${ }^{47}$ Képek forrása: a) Részlet Theophil Hansen Lüszikratész-emlékmühöz készített rekonstrukciós rajzából. https://upload.wikimedia.org/wikipedia/commons/f/f6/Theophil-hansen-lysikratesmonument.jpg (a letöltés ideje: 2016. február 18.) b) Részlet Theophil Hansen bécsi Parlement épületéről. (Wien, Dr. Karl Renner-Ring 3) A fotót a szerző készítette. c-d) Részlet Wágner Gyula debreceni bírósági épületéről. (Debrecen, Széchenyi u. 9.) A fotókat Batta Gergő készítette.
} 
Palota fejezeteivel és nagyoszloprendjével jól összekombinálható a debreceni épület homlokzati rendszerével (6. kép). ${ }^{48}$

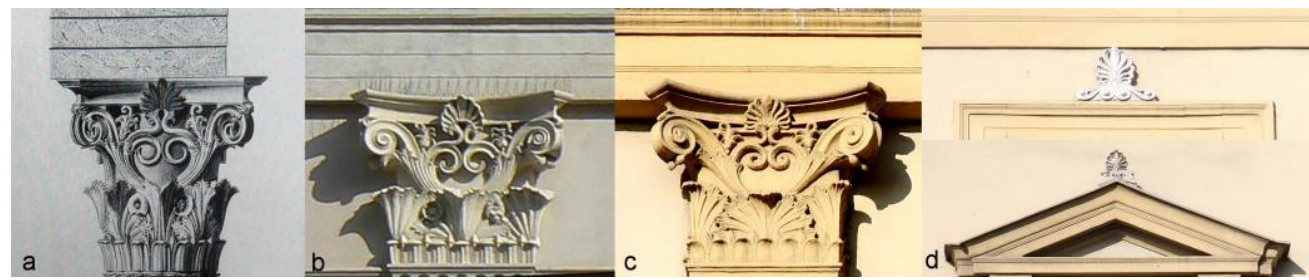

5. kép. Hansen rekonstrukciós rajza a Lüszikratész-emlékmüről (a) és oszlopföje a bécsi Parlament épületén (b), valamint Wágner oszlopföje (c), illetve palmettái (d) a debreceni Széchenyi utcán.

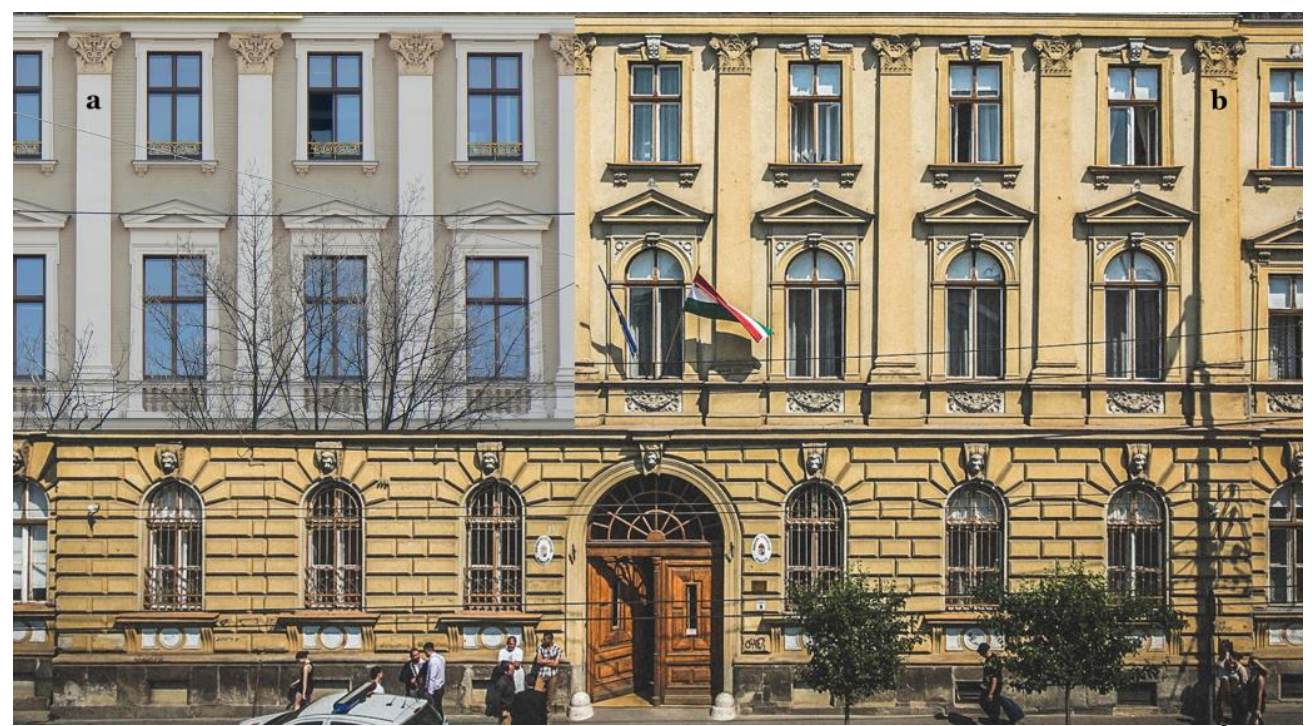

6. kép. Hansen bécsi Ephrussi Palotája (a) és Wágner debreceni egykori Királyi Ítélőtáblája (b) fotómontázson.

Egy másik ,apróság” is Hansenre utal Wágner debreceni épületén. Ez a nyíláskereteket díszítő akroterion, vagy másképp definiálva egy palmettás motívum. Ami úgy tünik, Hansen építészeti formaelemei körében szintén antik emlékekre utal. A bécsi Parlament épületén - amelynél Hansen kifejezett szándéka volt a „hellén stílus" alkalmazása - számos helyen felfedezhető e díszítőelem. Ha nem is ilyen tiszta alakjában, de ezek a palmetták a debreceni Széchenyi utcai épületen is láthatók. Wágner a nyíláskeretezés felső részét díszítette ezekkel, nemcsak a középrizalit első emeleti ablakainak timpanoncsúcsain, hanem azok szárain is megtalálhatók voltak. Ma sajnos ezek hiányoznak a homlokzatról. Továbbá a többi ablakkeret is kapott egy-egy palmetta középdíszt (5/d kép).

Ez a palmetta motívum nemcsak akroterionként, hanem a pilaszterek fejezetének egyik elemeként is megjelent Hansen formavilágában, s a tanítvány, Wágner

\footnotetext{
${ }^{48} \mathrm{~A}$ fotómontázst a szerző készítette saját (a) és Batta Gergő (b) fényképének felhasználásával.
} 
Gyula is átvette ezt. Egy példáról már volt szó, az egykori ítélőtábla épület, a mai Széchenyi utcai Debreceni Törvényszék középrizalitjának fejezeteiröl (5/c kép). De nem csak itt, hanem Wágner másik debreceni bírósági épületén, a volt Törvényszéki Palotán mai napig is találkozhat az éles szemü megfigyelő ezekkel az elemekkel. A Törvényszéki Palota a II. világháborús légitámadás után megmaradt, mai Iparkamara utcai szárnyának homlokzati pilaszterei is tükrözik tehát a hanseni formavilágot. A félemelettel magasabb középrizalitban ión, az oldalszárnyakon dór fejezetes pilasztereket láthatunk. Mindkét esetben megjelenik a palmetta motívum. A fejezetek kialakítása nagyon emlékeztet a bécsi Musikverein épületének díszeihez (7. kép). ${ }^{49}$

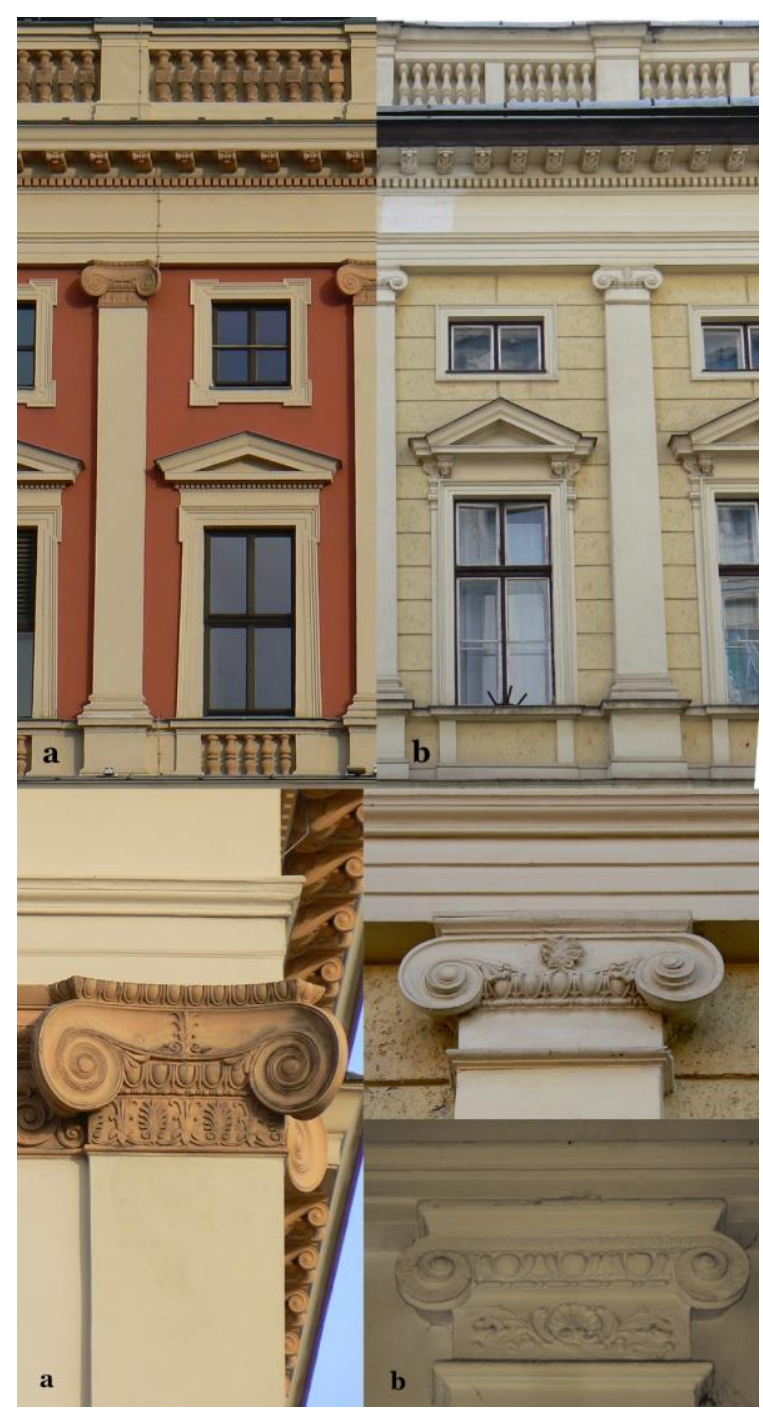

7. kép. Hansen bécsi Musikverein épületének (a) és Wágner debreceni Iparkamara utcai Törvényszéki Palotájának (b) részletei.

${ }^{49} \mathrm{~A}$ részletekről készült fényképeket a szerző készítette. 


\section{Az egykori Törvényszéki Palota épülete}

A teljesebb képhez ki kell térni a Törvényszéki Palota tömegalakítására is, amely a wágneri életmün belül ebből a szempontból egy másik csoportba tartozik. A föszárny kétkupolás sarokrizalitokkal hangsúlyozott középső traktusa jellegzetes tömeg- és homlokzatformálási megoldása volt az építésznek. Nemcsak a debreceni Törvényszéki Palota kapott ilyen külsőt, hanem a szatmárnémeti (1896), valamint a kassai ítélőtábla (1904) is. Ezek az épületek szinte egymás replikációinak tünnek. De ez a formarendszer feltünik a kecskeméti törvényszéki épületen (1897-1900), illetve a tömegelemeiben jobban megmozgatott kolozsvári (1900-1902), soproni (1896), újvidéki (1896) és gyulai (1897-1899) bíróságokon is. Ez utóbbi három épület - szinte azonos megjelenésük miatt - akár egy következő csoportját is képezheti Wágner házainak (8. kép) ${ }^{50}$

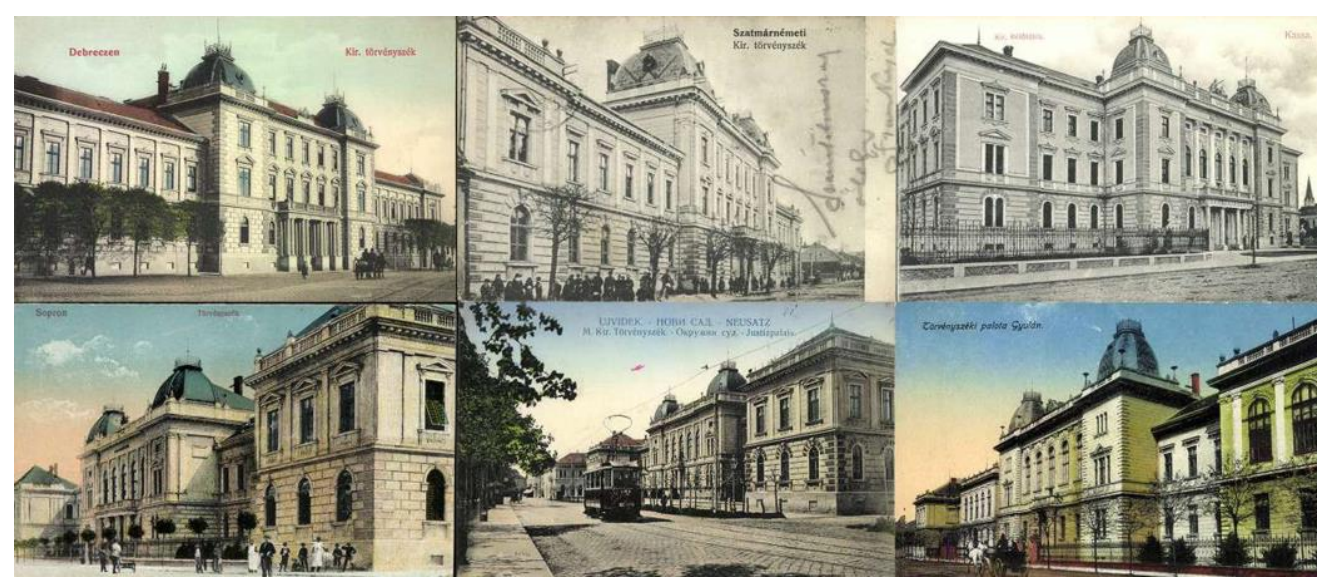

8. kép. Wágner Gyula kétkupolás bírósági épületei: Debrecen, Szatmárnémeti, Kassa,

Sopron, Újvidék, Gyula.

E kétkupolás középrizalitnak a kialakulása jól nyomon követhetö Hansen építészetében. Érdemes a folyamtat bemutatását Hansen Heinrich Drasche számára tervezett bérpalotájával, a Heinrichhoffal kezdeni.

Hansen önálló és csoportos lakóházakat is építet, amelyek közül az utóbbiak építészettörténetileg fontos szerepet játszanak. Az első ilyen több egységből álló háza volt Heinrichhof, amely karaktere szerint bérház volt ugyan, de a megjelenése palotaszerü, ekképp a városi paloták konkurált. A homlokzati kiképzése Hansen első neoreneszánsz épületének, a Sina Palotának a megoldásait követte. ${ }^{51} \mathrm{~A}$ homlokzaton a három egység jól elkülönül: a rusztikázott, földszintet is magába foglaló lábazat félköríves nyílásokkal. A kétemeletes felsö rész a vertikálisan összekötött ablaksorral, és a konzolszint.

A Heinrichhof első terve négy pavilonnal megemelt sarokrizalitos, a régi négyzetes formájú olasz castellumokból kifejlődött kastélyokhoz hasonlító épület volt. A

\footnotetext{
${ }^{50}$ Képek forrása: Hungaricana Képeslapok adatbázisa http://postcards.hungaricana.hu/hu/ (a letöltés ideje: 2016. február 18.)

${ }^{51}$ Wagner-Rieger, RenAte - Reissberger, Mara: Theophil von Hansen. Wiesbaden, 1980. 54.
} 
felépült épületen viszont a középrizalit nagyobb tömeget kapott, amivel az első terv széthúzott tömegü koncepcióját feladta ugyan a tervező, mégis harmonikus forma jött létre. ${ }^{52}\left(9\right.$. kép) ${ }^{53}$ Renate Wagner-Rieger szerint a megvalósult épület Hansen új stílusát teljesen megmutatta. ${ }^{54}$

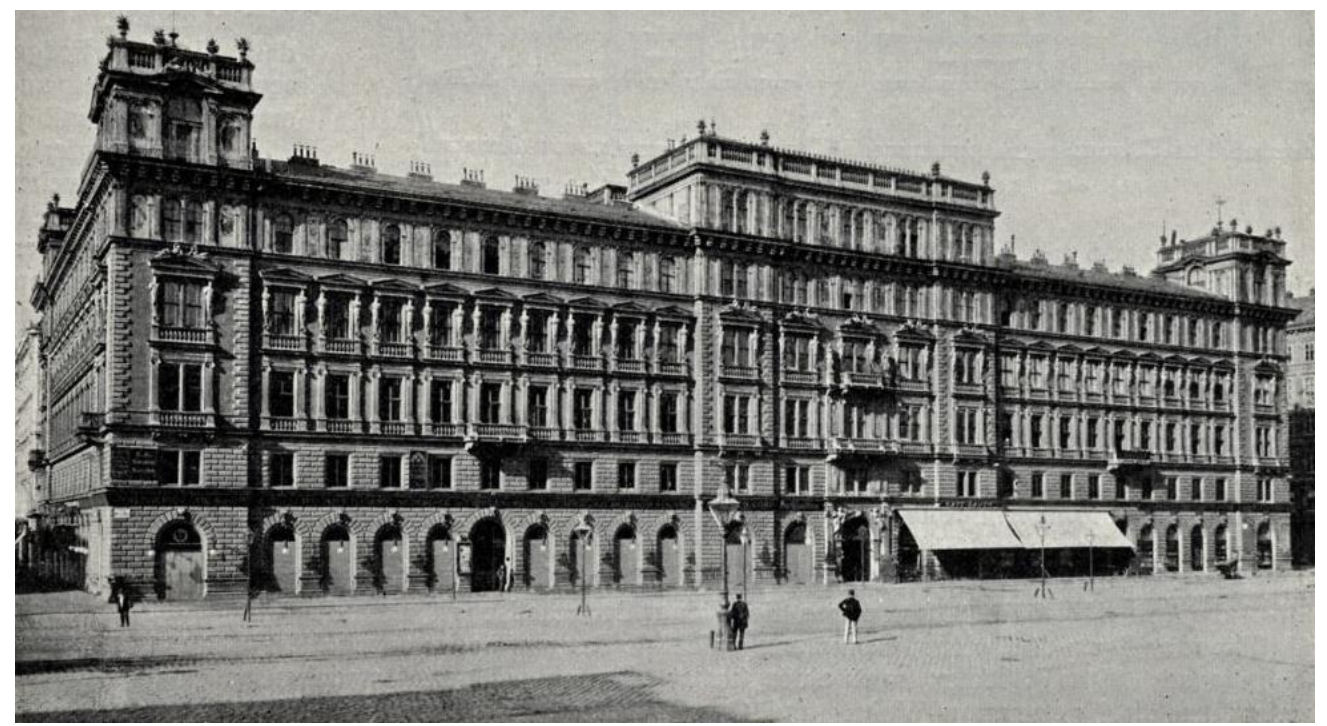

9. kép. Heinrichhof épülete a bécsi Opernringen. Az épületet a II. világháborúban elszenvedett károk miatt 1954-ben lebontották.

A folyamat következö eleme Hansen épületei körében az ún. Schottenring Komplex, vagyis a Schottenring 20-26. alá tervezett épületegyüttes. A 102 m hosszú és $46 \mathrm{~m}$ széles építési telken nyolc házat kellett építeni egy homlokzati rendszerbe foglalva. A tervezés folyamatát Renate Wagner-Rieger írta le, amiből kiderül, hogy a feladathoz Hansen két tervet készített. A korábbi közvetlenül kapcsolódott Heinrichhofhoz, csak méreteiben volt nagyobb. A külsőt tekintve ismét a castellumtípust alkalmazta, mint Heinrichhofnál, azonban a Schottenringen a sarokrizalitokat kupolával koronázta, amellyel erősítette az épület sarokhangsúlyos karakterét. A középső traktust a homlokzaton középrizalittal és attikával emelte meg, amely fölött a tető is elkülönült. Az, hogy ez a terv nem valósult meg, csak annak köszönhetö, hogy Hansen a nyolc parcellára, hat lakóházat tervezett, amit a tömegkialakítás szempontjából megrendelői kérésre át kellett formálnia. Négy kampóalakú házat rendezett négyszögbe egy udvar köré. A négyemeletes épület sarokrizalitjai kupolát kaptak. Emellé állított mindkét oldalon közös udvarral kampóalakú épületrészeket, amelyek csak három emeletesek voltak. ${ }^{55}$ Az így kialakult

\footnotetext{
${ }^{52}$ Schludermann, Maria: i. m., 44.

${ }^{53}$ Kép forrása: Wien am Anfang des XX. Jahrhunderts - Ein Führer in technischer und künstlerischer Richtung, Wien, 1906.

https://upload.wikimedia.org/wikipedia/de/8/88/GuentherZ_0033_Wien01_Opernring_Heinrichshof.jp g (a letöltés ideje: 2016. február 18.)

${ }^{54}$ WAGNER-RIEGER, RENATE - REISSBERGER, MARA: i. m., 63.

${ }^{55}$ WAGNER-RIEGER, RENATE - REISSBERgER, MARA: i. m., 66.
} 
forma ma is látható a bécsi Schottenringen. (10. kép) $)^{56}$ Wágner ezt a formát is átvette, s mint láttuk, több épületén is alkalmazta. Ekképp egy bécsi bérpalota formavilága egy magyar középület sajátjává vált, ami jól tükrözi a mintakövetés jelentőségét.

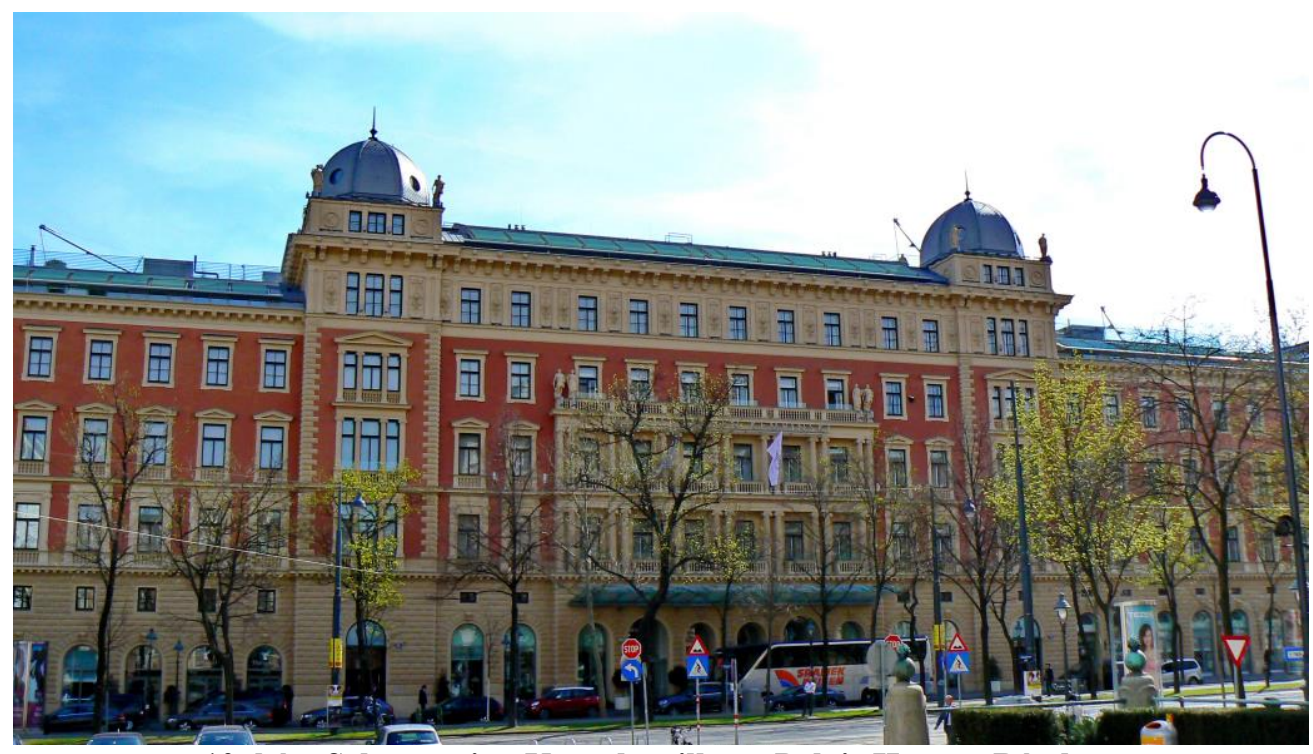

10. kép. Schottenring Komplex, illetve Palais Hansen Bécsben.

\section{Záró gondolatok - A stílus kérdése}

A homlokzatok egészét tekintve vitatható, hogy neoreneszánsz vagy neobarokk stílusról beszélhetünk. Wágner tulajdonképpen akkor, amikor a debreceni Magyar Királyi Ítélőtábla épületét tervezte már a neobarokk formálás jeleit mutatta az íves manzárdkupolájával, vagy nagyoszloprendjével. Azonban ahogy Sisa Józsefnél olvashatjuk: „A neoreneszánsz és a neobarokk között meglehetősen szabad volt az átjárás. Valójában sok épületen az architektúra formái sem pontosan definiálhatók vagy elhatárolhatók; a reneszánsz klasszikus tagozatai együtt járhattak a markánsabb barokk formákkal, a látványos, olykor bombasztikus kupolákkal." ${ }^{, 57}$ Ez a stíluskeveredés Wágner építészetével kapcsolatban is kétségbe ejthet bennünket. Nehezen definiálható a formakészlete, mégis valamilyen mértékben kategorizálhatunk. Azok az épületek tekinthetők a neobarokk irányában tett erőteljesebb lépésnek, amelynél Wágner jobban elszakadt a neoreneszánsz homlokzati elemektől. Ebben a felfogásban a kecskeméti, az egri, illetve a csíkszeredai épületeket lehet elsősorban ide sorolni. Viszont azok a házak, amelyek homlokzati eleminek gyökere megtalálható Hansen formavilágában, jobban örzik a neoreneszánsz karaktert. Ezen belül is sajátos ízt adnak nekik a görög antik részletek. Ez Hansen specialitása volt, akinek életútjából következett, hogy hamar megismerkedett a klasszikus antik formákkal. 1859-ben, amikor a neoreneszánsz felé fordult, nem hagyta el az általa megszeretett

\footnotetext{
${ }^{56}$ A fényképet a szerző készítette 2014 márciusában.

${ }^{57}$ SISA JÓZSEF (szerk.): i. m., 336.
} 
antik elemeket, éppen ellenkezőleg, a reneszánsz tömeg- és homlokzatformálási elveket vegyítette a görög antik részletformákkal. Ekképpen létrehozta sajátos stílusát, a „griechische Renaissance”-t, amelyet tanítványai, így Wágner Gyula is, Bécstől távol eső városokban is meghonosítottak. Ennek köszönhetően a „bécsi Styl” a debreceni falakról is visszaköszön. 